\title{
Sistem Informasi Pemasaran Hasil Pertanian Berbasis Android
}

\author{
Meylanie Olivya ${ }^{1}$ Ilham $^{2}$ \\ ${ }^{1}$ Teknik Elektro, Politeknik Negeri Ujung Pandang \\ ${ }^{1}$ meylanie@poliupg.ac.id \\ ${ }^{2}$ Teknik Informatika, STMIK AKBA \\ 2ilham_eng80@yahoo.com
}

\begin{abstract}
ASBSTRAK
Harga pasar hasil pertanian sering dimainkan oleh para tengkulak. Mereka membeli hasil pertanian dari para petani dengan harga yang lebih rendah dari harga pasar sehingga petani mengalami kerugian. Penelitian ini bertujuan untuk membangun sistem yang dapat menyebarkan informasi mengenai harga pasar hasil pertanian kepada para petani. Sistem ini terdiri atas dua bagian yaitu admin dan user. Bagian admin berfungsi untuk memasukkan jenis dan harga hasil pertanian. Sedangkan bagian user diperuntukkan untuk petani agar dapat melihat informasi harga pasar hasil pertanian. Sistem yang dibangun berbasis android sehingga memudahkan untuk mendapatkan informasi. Dengan demikian, diharapkan agar kerugian yang selama ini dialami oleh petani dapat diatasi.
\end{abstract}

Kata kunci : harga pasar, hasil pertanian, sistem informasi, android

\section{Pendahuluan}

Peranan sektor pertanian dalam pembangunan ekonomi di Indonesia sangatlah penting. Hal ini disebabkan oleh sebagian besar masyarakat Indonesia masih menggantungkan hidupnya pada sektor tersebut, terutama sebagai penyedia bahan kebutuhan pokok. Kebutuhan pokok dalam kehidupan meliputi 3 hal, yaitu sandang, pangan dan papan. Dalam perjalanannya, ketiga kebutuhan pokok manusia tersebut menjadi bertambah dan bahkan tidak tergantikan, yakni kebutuhan informasi. Bahkan kebutuhan informasi di era globalisasi ini telah menambah anggaran biaya kehidupan manusia untuk memperoleh informasi terbaru maupun saling bertukar informasi.

Minimnya informasi di sektor pertanian merupakan penghambat proses memperoleh informasi di era teknologi dan informasi yang semakin berkembang saat ini. Sehingga saat ini masih banyak hasil pertanian tidak terdistribusi dengan baik dan terjadinya permainan harga yang di lakukan oleh tengkulak yang tidak bertanggung jawab.

Sistem informasi yang membahas mengenai harga barang di sektor pertanian bagian pangan sangatlah jarang. Terutama sistem informasi mengenai harga penjualan hasil pertanian. Atas dasar itulah, penyusun ingin membangun sistem informasi pemasaran hasil pertanian khususnya di bidang pangan dengan tujuan petani dapat memasarkan hasil produksinya ke seluruh Indonesia tanpa campur tangan tengkulak yang tidak bertanggung jawab.

Berdasarkan permasalahan di atas dan semakin berkembangnya teknologi secara pesat, maka diperlukan suatu media yang dapat memandu dan memberikan informasi dengan cepat. Android adalah sistem operasi mobile yang akhir-akhir ini menjadi popular di kalangan smartphone. Android adalah sistem operasi berbasis open source sehingga pengguna bisa membuat aplikasi baru di dalamnya. Dalam penelitian ini akan dibangun sistem informasi mengenai harga pasar hasil pertanian berbasis android. Dengan 
demikian, diharapkan dapat mengatasi kerugian dari para petani akibat permainan harga pasar.

\section{Metodologi Penelitian}

Tahapan-tahapan dalam penelitian ini ditunjukkan pada Gambar 1.

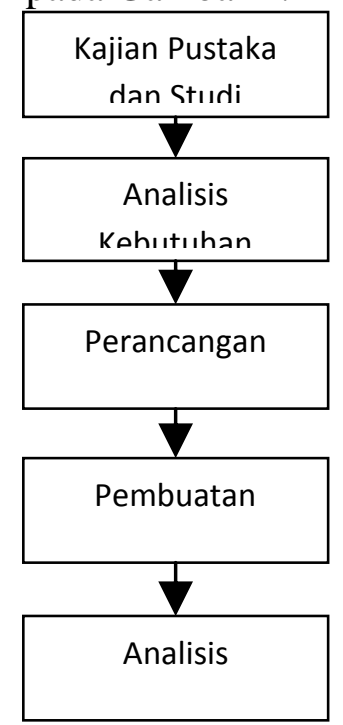

Gambar 1. Prosedur Penelitian

\section{A. Kajian Pustaka dan Studi Literatur}

Pada tahapan ini dilakukan kajian pustaka dan studi literatur terhadap beberapa referensi yang relevan dengan topik penelitian. Adapun referensi yang dirujuk dalam penelitian ini adalah beberapa penelitian yang berkaitan dengan topik penelitian, sistem Informasi, pemasaran dan pemrograman android yang akan digunakan dalam merancang aplikasi.

\section{B. Analisis Kebutuhan Sistem}

Sistem yang akan dibangun memiliki dua aktor yang akan berinteraksi langsung dengan sistem. Kedua aktor tersebut adalah Admin dan User. Aktor Admin bertugas untuk menambah user, menambah tanaman, mengedit tanaman, menghapus tanaman, melihat jenis tanaman dan info harga pada sistem. Sedangkan User dapat melihat jenis tanaman dan melihat info harga. Gambar 2 dan 3 menunjukkan diagram use case untuk admin dan user.

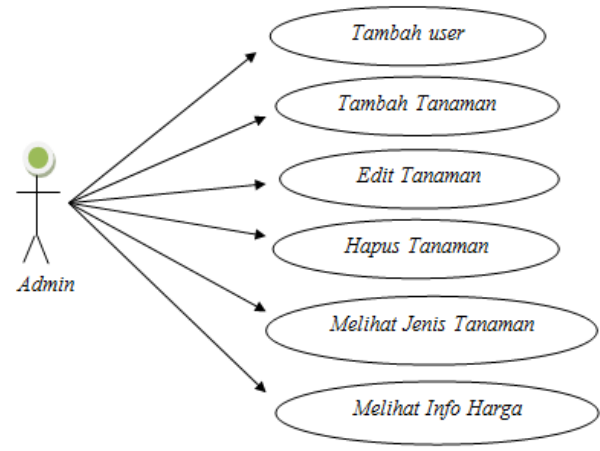

Gambar 2. Diagram use case Admin

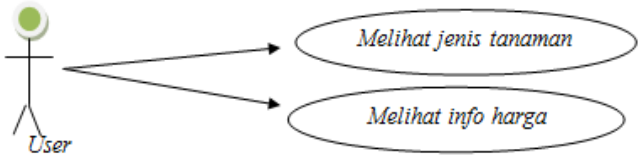

Gambar 3. Diagram use case User

\section{Perancangan Sistem}

Tahapan perancangan aplikasi merupakan lanjutan dari tahapan analisis kebutuhan sistem. Perancangan sistem akan sepenuhnya mengacu pada analisis kebutuhan sistem. Sistem akan dibagi ke dalam dua bagian yaitu Admin dan User.

\section{Pembuatan Sistem}

Sistem yang akan dibangun berbasis android dengan dua bagian antarmuka sesuai dengan perancangan yang telah dibuat.

\section{E. Analisis Sistem}

Pada tahapan ini, akan dilakukan analisis sistem yang telah dibuat berdasarkan analisis kebutuhan sistem. Analisis ini bertujuan untuk mengetahui apakah sistem yang dibangun telah sesuai dengan analisis kebutuhan yang telah dibuat sebelumnya.

\section{Hasil dan Pembahasan}

Pada bab ini akan di jelaskan secara detail mengenai arsitektur sistem, implementasi dan analisis sistem. Berikut merupakan beberapa tampilan antarmuka aplikasi pada perangkat android. 


\section{A. Antarmuka Sistem Pada Admin}

Berikut adalah beberapa tampilan antarmuka sistem pada admin.

1) Antarmuka menu utama: Gambar 4 menunjukkan tampilan Menu Utama yang terdiri atas 3 Menu yaitu Menu Pertanian, Menu Perkebunan dan Menu Daftar User. Pada Menu Pertanian dan Menu Perkebunan berfungsi untuk melihat informasi harga hasil pertanian dan perkebunan sebelum dan setelah melakukan perubahan informasi. Pada Menu Daftar User berfungsi melihat daftar user yang menggunakan aplikasi tersebut.

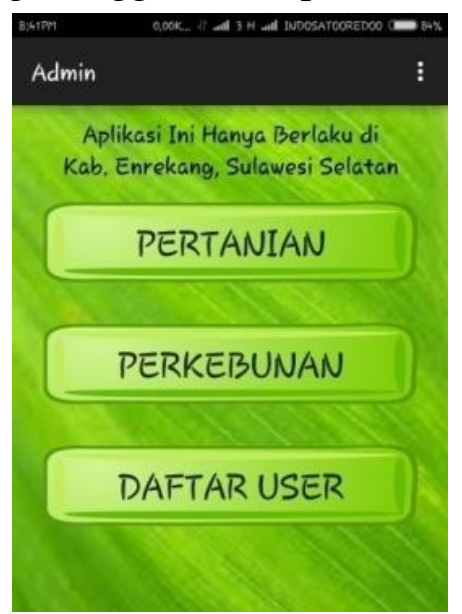

Gambar 4. Antarmuka menu utama pada Admin

2) Antarmuka Menu Pilihan: Gambar 5 merupakan tampilan menu pilihan pada admin. Pada menu pilihan tersebut terdapat beberapa pilihan yaitu Logout, Tambah Tanaman, Tambah User, Edit atau Hapus Tanaman, Petunjuk dan Keluar.

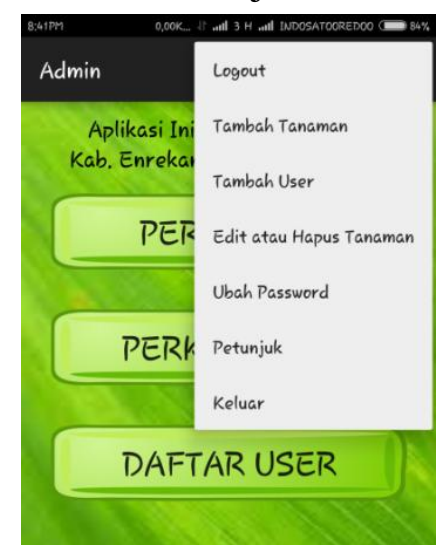

Gambar 5. Antarmuka menu Pilihan pada Admin
3) Antarmuka Tambah Tanaman: Gambar 6 menunjukkan tampilan menu Tambah Tanaman pada Admin. Menu tersebut digunakan untuk menambah jenis tanaman pertanian baru.

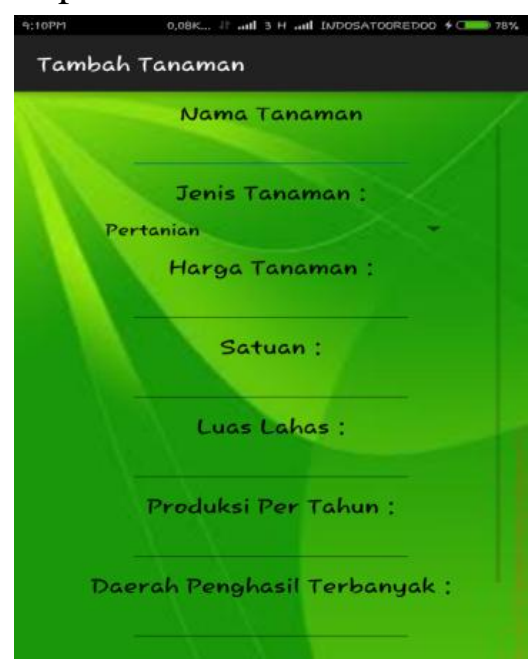

Gambar 6. Antarmuka menu Tambah Tanaman pada Admin

4) Antarmuka Edit Tanaman: Gambar 7 menunjukkan tampilan menu Edit Tanaman. Menu tersebut digunakan jika terjadi perubahan pada tanaman misalkan terjadi perubahan harga dan peningkatan atau penurunan produksi pertahun.

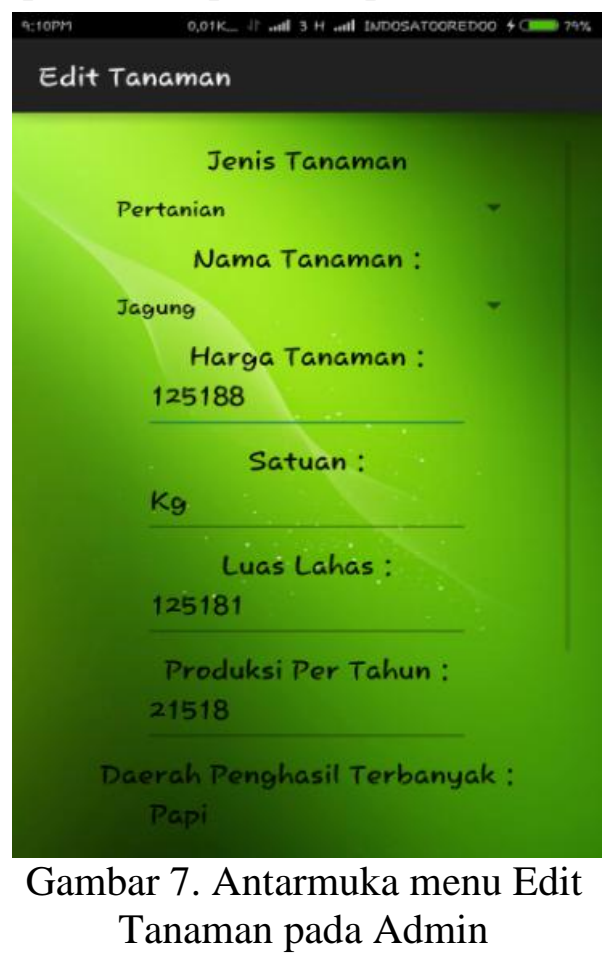




\section{B. Antarmuka Sistem pada User}

Berikut adalah beberapa tampilan antarmuka sistem pada user.

1) Antarmuka menu utama: Gambar 8 merupakan tampilan menu utama pada user. Pada tampilan tersebut terdapat 2 menu yaitu menu pertanian dan menu perkabunan. Menu tersebut merupakan kelompok jenis tanaman yaitu jenis tanaman pertanian dan tanman perkebunan.

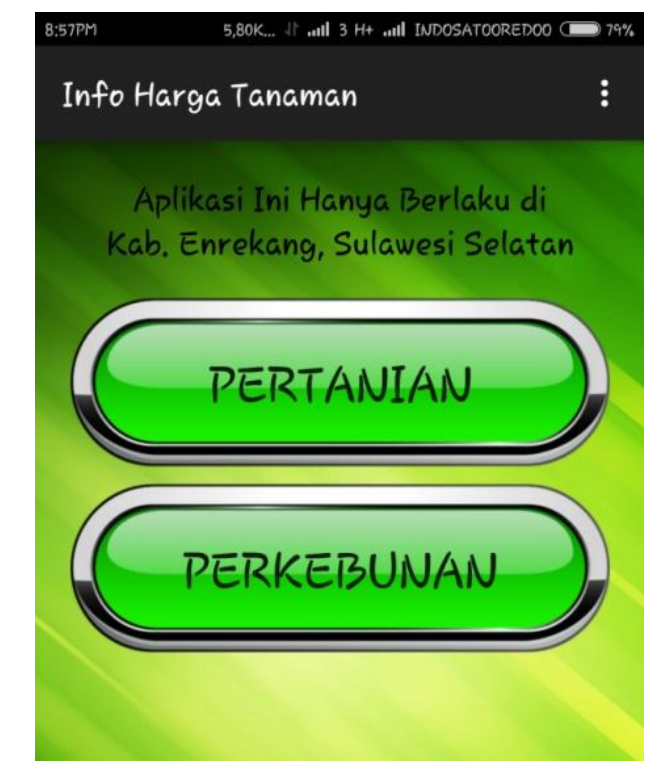

Gambar 8. Antarmuka menu utama pada User

2) Antarmuka Menu Pilihan: Gambar 9 merupakan tampilan jenis tanaman yang dikelompokkan berdasarkan komoditinya. Pada gambar tersebut ditampilkan beberapa jenis tanaman pertanian.

3) Antarmuka Info Harga Tanaman: Gambar 10 merupakan tampilan menu info harga tanaman, dimana pada menu tersebut terdapat informasi tentang informasi haga tanaman, luas lahan, produksi pertahun, daerah penghasil terbanyak dan waktu diperbaruinya informasi.

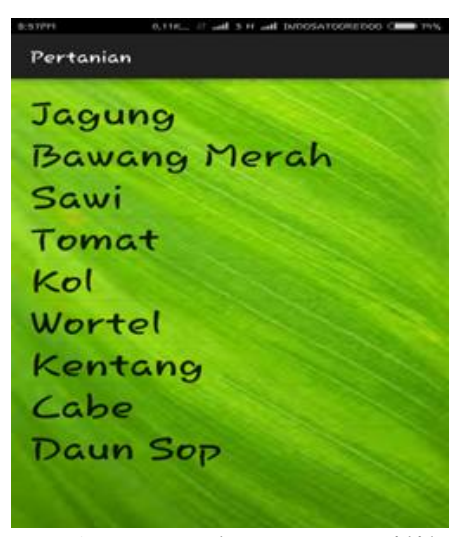

Gambar 9. Antarmuka menu Pilihan pada User

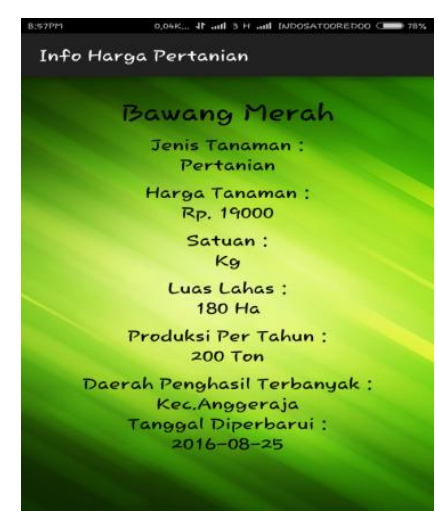

Gambar 10. Antarmuka Info Harga Tanaman pada User

\section{Pengujian Sistem}

Pengujian sistem dilakukan dengan dua metode yaitu metode black box dan metode kuesioner. Metode black box bertujuan menguji kesesuaian hasil pembuatan sistem terhadap analisis kebutuhan yang telah dibuat sebelumnya. Sedangkan metode survey dilakukan untuk mengetahui kelayakan sistem yang telah dibangun.

\section{1) Pengujian dengan Metode Black Box}

Hasil pengujian dengan metode BlackBox pada Admin ditunjukkan pada Tabel 1. Tabel tersebut menunjukkan kesesuaian antara hasil pembuatan sistem dan analisis kebutuhan sistem. Sedangkan pada Tabel 2 menunjukkan hasil pengujian terhadap User. 
Tabel 1. Hasil Pengujian dengan metode Black Box pada Admin

\begin{tabular}{|c|c|c|c|}
\hline Kelas Uji & Skenario Uji & $\begin{array}{l}\text { Hasil Yang } \\
\text { Diharapkan }\end{array}$ & Kesim-pulan \\
\hline $\begin{array}{l}\text { Tampilan Login } \\
\text { Pada Admin }\end{array}$ & $\begin{array}{lr}\text { Tekan tombol login } \\
\text { setelah } & \text { memasukan } \\
\text { username dan password }\end{array}$ & $\begin{array}{l}\text { Tampil Menu Utama } \\
\text { Yaitu Pertanian, } \\
\text { Perkebunan dan } \\
\text { Daftar User }\end{array}$ & Berhasil \\
\hline \multirow[t]{3}{*}{ Menu Utama } & Tekan tombol Pertanian & $\begin{array}{l}\text { Tampil Jenis } \\
\text { Tanaman Pertanian }\end{array}$ & Berhasil \\
\hline & $\begin{array}{ll}\text { Tekan } & \text { Tombol } \\
\text { Perkebunan } & \end{array}$ & $\begin{array}{ll}\text { Tampil Jenis } \\
\text { Tanaman } \\
\text { Perkebunan }\end{array}$ & Berhasil \\
\hline & $\begin{array}{l}\text { Tekan Tombol Daftar } \\
\text { User }\end{array}$ & Tampil Daftar User & Berhasil \\
\hline $\begin{array}{ll}\text { Jenis } & \text { Tanaman } \\
\text { Pertanian } & \end{array}$ & Tekan tanaman Pertanian & $\begin{array}{l}\text { Tampil Menu Info } \\
\text { Harga }\end{array}$ & Berhasil \\
\hline \multirow[t]{7}{*}{ Menu Pilihan } & Tekan logout & Tampil Menu Login & Berhasil \\
\hline & Tekan tambah tanaman & $\begin{array}{l}\text { Tampil Menu } \\
\text { Tambah Tanaman }\end{array}$ & Berhasil \\
\hline & Tekan tambah user & $\begin{array}{l}\text { Tampil Menu } \\
\text { Tambah User }\end{array}$ & Berhasil \\
\hline & $\begin{array}{l}\text { Tekan edit atau hapus } \\
\text { tanaman }\end{array}$ & $\begin{array}{l}\text { Tampil Menu Edit } \\
\text { atau Hapus Tanaman }\end{array}$ & Berhasil \\
\hline & Tekan Ubah Password & $\begin{array}{l}\text { Tampil Menu Ubah } \\
\text { Password }\end{array}$ & Berhasil \\
\hline & Tekan Petunjuk & $\begin{array}{l}\text { Tampil } \quad \text { Menu } \\
\text { Petunjuk }\end{array}$ & Berhasil \\
\hline & Tekan Keluar & Keluar dari Aplikasi & Berhasil \\
\hline $\begin{array}{ll}\text { Menu } & \text { Tambah } \\
\text { Tanaman } & \end{array}$ & $\begin{array}{l}\text { Menambahkan Jenis } \\
\text { Tanaman Pertanian atau } \\
\text { Perkebunan }\end{array}$ & $\begin{array}{l}\text { Tanaman Tersimpan } \\
\text { di Database }\end{array}$ & Berhasil \\
\hline $\begin{array}{l}\text { Menu Edit atau } \\
\text { Hapus Tanaman }\end{array}$ & $\begin{array}{l}\text { Mengedit atau } \\
\text { Menghapus Tanaman } \\
\text { Perkebunan / Pertanian } \\
\end{array}$ & $\begin{array}{l}\text { Tanaman berubah } \\
\text { atau terhapus di } \\
\text { Database }\end{array}$ & Berhasil \\
\hline $\begin{array}{ll}\text { Menu } & \text { Ubah } \\
\text { Password } & \\
\end{array}$ & $\begin{array}{ll}\text { Mengubah } & \text { Password } \\
\text { Pada Admin } & \\
\end{array}$ & Password Berubah & Berhasil \\
\hline $\begin{array}{ll}\text { Menu } & \text { Tambah } \\
\text { User } & \end{array}$ & Menambah User & $\begin{array}{l}\text { User Tersimpan di } \\
\text { Database }\end{array}$ & Berhasil \\
\hline Menu Petunjuk & Tekan Tombol Petunjuk & $\begin{array}{l}\text { Tampil Petunjuk } \\
\text { Untuk Admin }\end{array}$ & Berhasil \\
\hline Menu Keluar & Tekan Tombol Keluar & Keluar Dari Aplikasi & Berhasil \\
\hline
\end{tabular}


Tabel 2. Hasil Pengujian dengan metode Black Box pada User

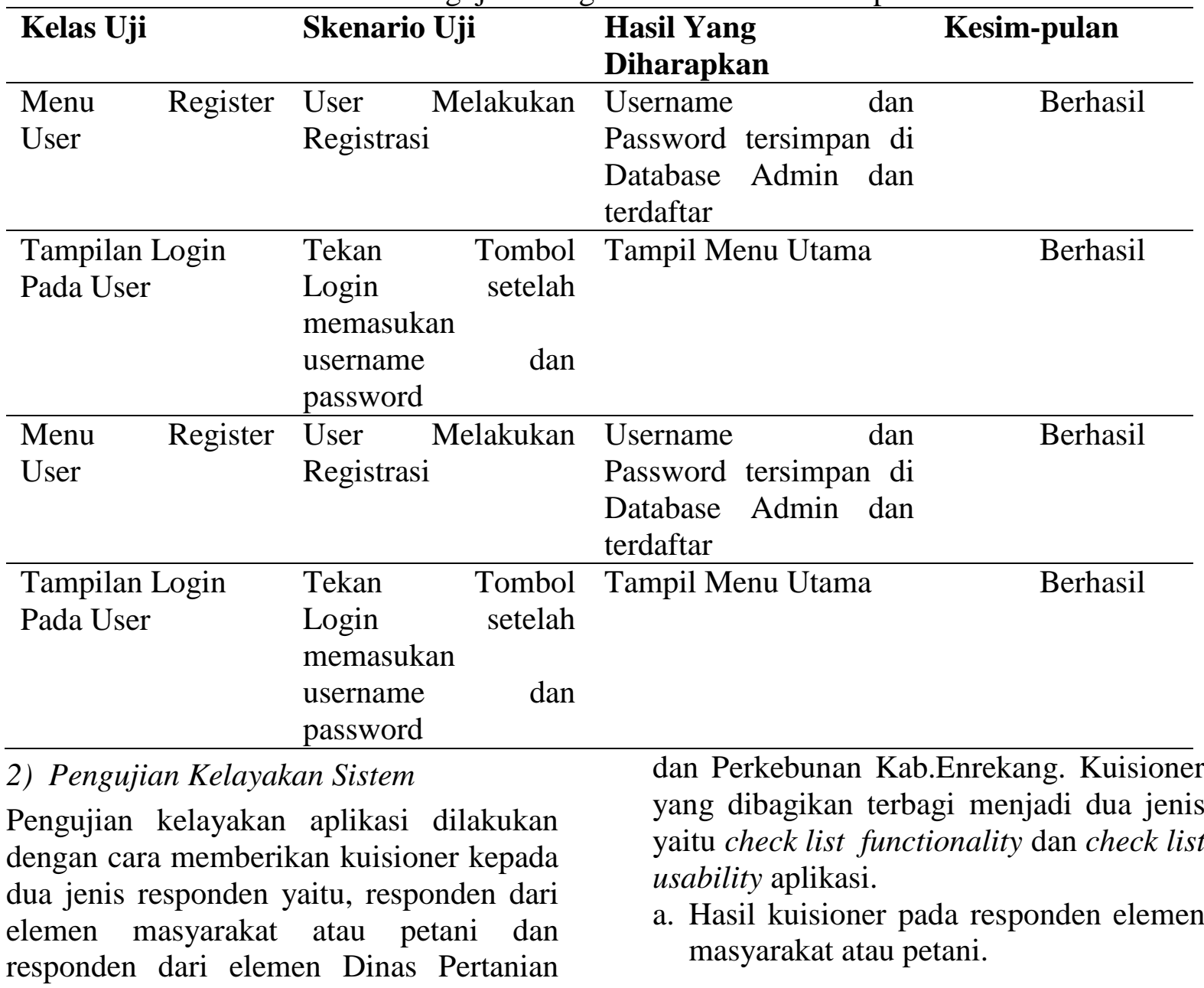

Tabel 3 Hasil kuisioner check list functional elemen masyarakat atau petani

\begin{tabular}{|c|c|c|c|}
\hline No & Pertanyaan & Ya & Tidak \\
\hline 1 & $\begin{array}{c}\text { Apakah aplikasi ini sudah berjalan dengan baik } \\
\text { dan berfungsi semestinya pada smartphone anda? }\end{array}$ & 10 & 0 \\
\hline 2 & $\begin{array}{l}\text { Apakah fungsi register sudah berjalan dengan } \\
\text { semestinya? }\end{array}$ & 8 & 2 \\
\hline 3 & $\begin{array}{c}\text { Apakah fungsi login sudah berjalan dengan } \\
\text { semestinya? }\end{array}$ & 10 & 0 \\
\hline 4 & $\begin{array}{c}\text { Apakah fungsi jenis tanaman sudah berjalan } \\
\text { dengan semestinya? }\end{array}$ & 10 & 0 \\
\hline 5 & $\begin{array}{c}\text { Apakah fungsi info harga sudah berjalan dengan } \\
\text { semestinya? }\end{array}$ & 7 & 3 \\
\hline 6 & $\begin{array}{c}\text { Apakah fungsi ubah password sudah berjalan } \\
\text { dengan semestinya? }\end{array}$ & 8 & 2 \\
\hline 7 & $\begin{array}{c}\text { Apakah fungsi logout sudah berjalan dengan } \\
\text { semestinya? }\end{array}$ & 9 & 1 \\
\hline & Total & 62 & 8 \\
\hline
\end{tabular}


Dari hasil kuisioner diatas dapat di lihat pada Tabel .3 dan Gambar 11 untuk mengetahui persentase masing-masing penilaian adalah:

Ya : $(62 / 70) \times 100 \%=88,57 \%$

Tidak : $(8 / 70) \times 100 \%=11,43 \%$

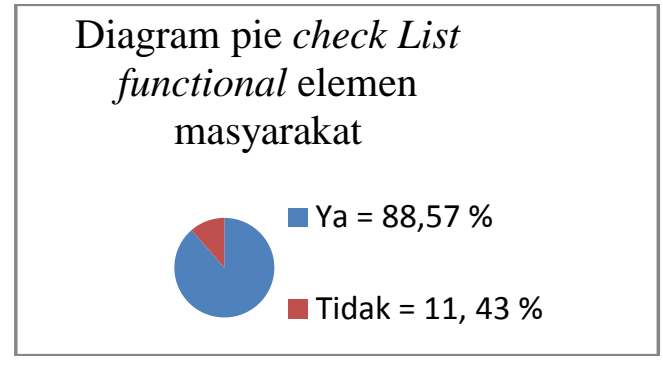

Gambar 11. Diagram pie check List functional elemen masyarakat

Tabel 4. Hasil kuisioner Check List Usability Aplication elemen masyarakat

\begin{tabular}{|c|c|c|c|c|c|}
\hline NO & Pertanyaan & TS & $\mathbf{K S}$ & $\mathbf{S}$ & $\mathbf{S S}$ \\
\hline 1 & $\begin{array}{l}\text { Secara keseluruhan, saya } \\
\text { puas dengan kemudahan } \\
\text { pemakaian aplikasi ini }\end{array}$ & 0 & 0 & 10 & 0 \\
\hline 2 & $\begin{array}{l}\text { Penggunaan aplikasi ini } \\
\text { sangat sederhana }\end{array}$ & 0 & 0 & 8 & 2 \\
\hline 3 & $\begin{array}{l}\text { Saya mendapatkan info } \\
\text { dengan cepat } \\
\text { menggunakan aplikasi ini }\end{array}$ & 0 & 0 & 6 & 4 \\
\hline 4 & $\begin{array}{l}\text { Saya mendapat info yang } \\
\text { akurat dengan aplikasi ini }\end{array}$ & 0 & 1 & 9 & 0 \\
\hline 5 & $\begin{array}{l}\text { Antarmuka aplikasi ini } \\
\text { menyenangkan }\end{array}$ & 0 & 2 & 8 & 0 \\
\hline 6 & $\begin{array}{l}\text { Aplikasi ini memiliki } \\
\text { fungsi yang kapabilitas } \\
\text { sesuai dengan harapan saya }\end{array}$ & 0 & 1 & 9 & 0 \\
\hline 7 & $\begin{array}{l}\text { Secara keseluruhan, saya } \\
\text { puas dengan aplikasi ini }\end{array}$ & 0 & 2 & 8 & 0 \\
\hline Total & & $\mathbf{0}$ & 6 & 58 & 6 \\
\hline
\end{tabular}

Dari hasil diatas dapat lihat pada Tabel 4 dan Gambar 12 untuk mengetahui persentase masing-masing penilaian adalah:

Tidak Setuju (TS): (0/70) x 100\% $=0 \%$ Kurang Setuju (KS): (6/70) x 100\%= $8,57 \%$

Setuju (S) $\quad:(58 / 70) \times 100 \%=82,58 \%$ Sangat Setuju (SS): $(6 / 70) \times 100 \%=$ $8,57 \%$

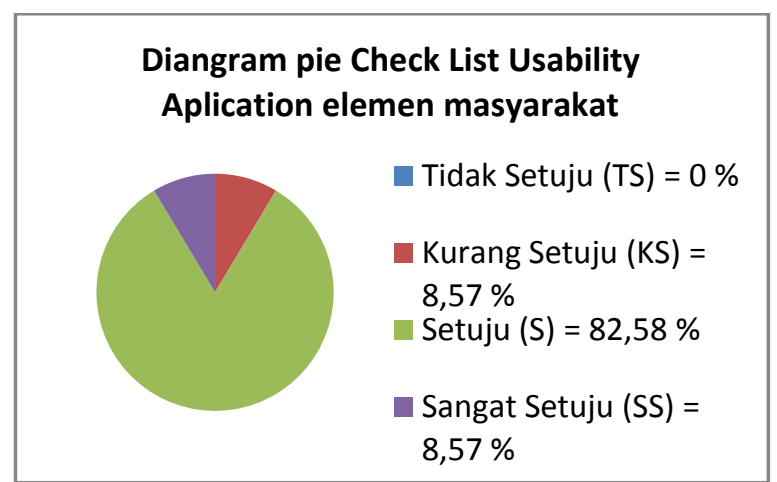

Gambar 12. Diagram pie check List Usability Aplication elemen masyarakat 
b. Hasil kuisioner dari elemen Dinas

9

Dari sisi admin, apakah

$4 \quad 1$

Pertanian dan Perkebunan Kab.

fungsi edit atau hapus

Enrekang.

Tabel 5 Hasil kuisioner check list tanaman sudah berjalan dengan baik?

functional elemen Dinas Pertanian dan Perkebunan Kab.Enrekang

\begin{tabular}{|c|c|c|c|}
\hline No & Pertanyaan & $\mathrm{Ya}$ & Tida \\
\hline 1 & $\begin{array}{l}\text { Apakah aplikasi ini } \\
\text { sudah berjalan dengan } \\
\text { baik dan berfungsi } \\
\text { semestinya } \\
\text { smartphone anda? }\end{array}$ & 5 & 0 \\
\hline 2 & $\begin{array}{l}\text { Apakah fungsi register } \\
\text { sudah berjalan dengan } \\
\text { semestinya? }\end{array}$ & 5 & 0 \\
\hline 3 & $\begin{array}{l}\text { Apakah fungsi login } \\
\text { sudah berjalan dengan } \\
\text { semestinya? }\end{array}$ & 5 & 0 \\
\hline 4 & $\begin{array}{l}\text { Apakah fungsi jenis } \\
\text { tanaman sudah berjalan } \\
\text { dengan semestinya? }\end{array}$ & 5 & 0 \\
\hline 5 & $\begin{array}{l}\text { Apakah fungsi info harga } \\
\text { sudah berjalan dengan } \\
\text { semestinya? }\end{array}$ & 5 & 0 \\
\hline 6 & $\begin{array}{l}\text { Apakah fungsi ubah } \\
\text { password sudah berjalan } \\
\text { dengan semestinya? }\end{array}$ & 4 & 1 \\
\hline 7 & $\begin{array}{l}\text { Apakah fungsi logout } \\
\text { sudah berjalan dengan } \\
\text { semestinya? }\end{array}$ & 5 & 0 \\
\hline 8 & $\begin{array}{l}\text { Dari sisi admin, apakah } \\
\text { fungsi tambah tanaman } \\
\text { sudah berjalan dengan } \\
\text { baik? }\end{array}$ & 4 & 1 \\
\hline
\end{tabular}

10 Dari sisi admin, apakah 32 fungsi tambah user sudah berjalan dengan baik?

$\begin{array}{lll}\text { Total } & 45 & 5\end{array}$

Dari hasil kuisioner diatas dapat di lihat pada Tabel 5 dan Gambar 13 untuk mengetahui persentase masing-masing penilaian adalah:

Ya $\quad:(45 / 50) \times 100 \%=90 \%$

Tidak $\quad:(5 / 50) \times 100 \%=10 \%$

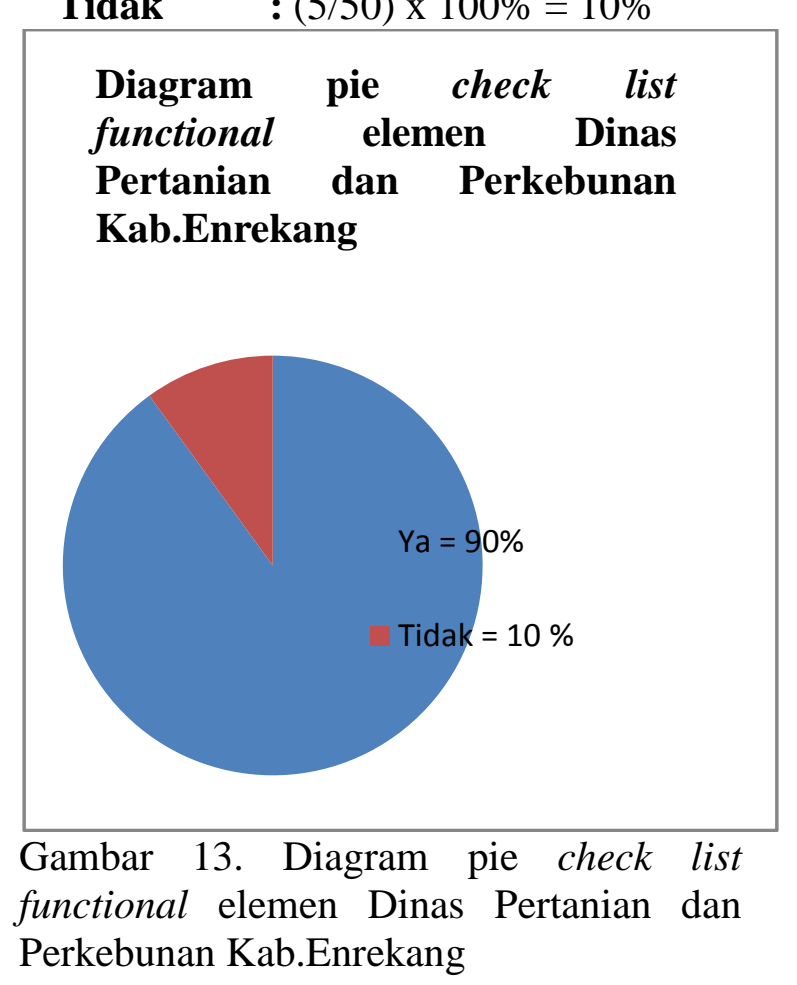

Tabel 6 Hasil kuisioner Check List Usability Aplication elemen Dinas Pertanian dan Perkebunan Kab.Enrekang

\begin{tabular}{cccccc}
\hline NO & Pertanyaan & TS & KS & S & SS \\
\hline 1 & $\begin{array}{c}\text { Secara keseluruhan, saya puas } \\
\text { dengan kemudahan pemakaian } \\
\text { aplikasi ini }\end{array}$ & 0 & 0 & 5 & 0 \\
2 & $\begin{array}{c}\text { Penggunaan aplikasi ini sangat } \\
\text { sederhana }\end{array}$ & 0 & 0 & 4 & 1 \\
3 & $\begin{array}{l}\text { Saya mendapatkan info dengan } \\
\text { cepat menggunakan aplikasi ini }\end{array}$ & 0 & 0 & 3 & 2
\end{tabular}




\begin{tabular}{cccccc}
\hline NO & Pertanyaan & TS & KS & S & SS \\
\hline 4 & $\begin{array}{c}\text { Saya mendapat info yang akurat } \\
\text { dengan aplikasi ini }\end{array}$ & 0 & 0 & 5 & 0 \\
5 & $\begin{array}{c}\text { Antarmuka aplikasi ini } \\
\text { menyenangkan }\end{array}$ & 0 & 1 & 4 & 0 \\
6 & $\begin{array}{c}\text { Aplikasi ini memiliki fungsi } \\
\text { yang kapabilitas sesuai dengan } \\
\text { harapan saya }\end{array}$ & 0 & 1 & 4 & 0 \\
7 & $\begin{array}{c}\text { Secara keseluruhan, saya puas } \\
\text { dengan aplikasi ini } \\
8\end{array}$ & 0 & 1 & 4 & 0 \\
$\begin{array}{c}\text { Dari sisi admin, mengontrol } \\
\text { informasi dari panel admin ini } \\
\text { mudah digunakan } \\
\text { Dari sisi admin, mengupdate } \\
\text { informasi dari panel admin in } \\
\text { tidak merepotkan admin }\end{array}$ & 0 & 0 & 4 & 1 \\
\hline Total & 0 & 0 & 4 & 1 \\
\hline
\end{tabular}

Dari hasil diatas dapat diketahui persentase untuk masing penilaian adalah:

Tidak Setuju (TS) : $(0 / 45) \times 100 \%=$ $0 \%$

Kurang Setuju (KS) : (3/45) $\quad \mathrm{x}$

$100 \%=6,67 \%$

Setuju (S) : $(37 / 45) \times 100 \%=82,22 \%$

Sangat Setuju (SS): $(5 / 45) \times 100 \%=$ $11,11 \%$

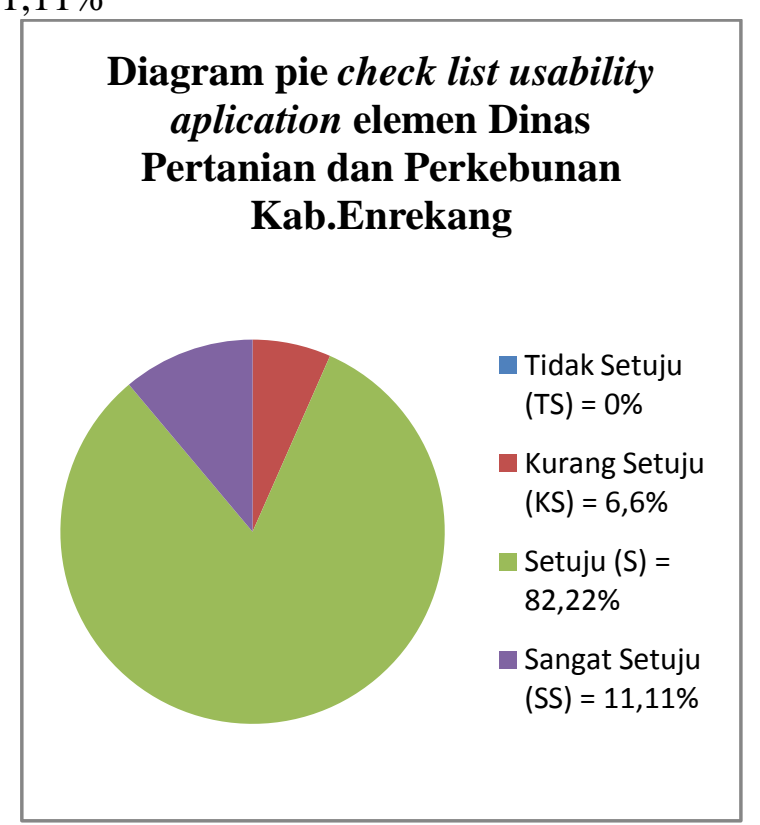

Gambar 14. Diagram pie check list usability aplication elemen Dinas

Pertanian dan Perkebunan Kab.Enrekang

Berdasarkan hasil kuisioner check list functional pada 10 responden $88.57 \%$ responden elemen masyarakat menyatakan fungsi dari aplikasi ini sudah berjalan sebagai mana mestinya dan pada 5 responden dari elemen Dinas Pertanian Kab.Enerekang 90\% mengatakan bahwa aplikasi ini sudah berjalan sebagaimana mestinya, sedangkan $11.43 \%$ responden dari elemen masyarakat dan $10 \%$ responden dari elemen Dinas Pertanian Kab.Enrekang mengatakan tidak. Hal ini mungkin dikarenakan terjadinya gangguan pada jaringan di saat mereka menggunakan aplikasi tersebut sehingga tidak berjalan dengan lancar.

Berdasarkan hasil kuisioner check list usability aplication 0\% responden dari elemen masyarakat dan responden dari elemen Dinas Pertanian dan Perkebunan Kab.Enrekang mengatakan tidak setuju, $8,57 \%$ responden dari elemen masyarakat dan $6,67 \%$ responden dari elemen Dinas Pertanian dan Perkebunan Kab.Enrekang mengatakan kurang setuju, 82,58\% responden dari elemen nasyarakat dan $82,22 \%$ responden dari elemen Dinas Pertanian dan Perkebunan Kab.Enrekang mengatkan setuju dan $8,57 \%$ responden dari elemen masyarakat dan $11,11 \%$ responden dari dari elemen Dinas Pertanian dan Perkebunan Kab.Enrekang mengatakan sangat setuju. 


\section{IV.KESIMPULAN}

Dari pembahasan yang diuraikan maka penyusun menarik kesimpulan sebagai berikut.

Sistem Informasi Pemasaran Hasil Bumi di Kab.Enrekang ini berhasil dibuat dan dapat dijadikan acuan oleh masyarakat untuk memperoleh informasi mengenai harga tanaman pertanian dan perkebunan dengan mudah dan tepat dikarenakan proses aplikasi ini berjalan secara real time.

Berdasarkan hasil kuisioner check list functional dan check list usability, aplikasi ini berguna bagi masyarakat dalam menyajikan informasi mengenai harga

\section{DAFTAR PUSTAKA}

Ilham Andi Muhammad.(2015). Perancangan Aplikai Informasi Rumah Sakit Berbasis Mobile. Makassar: Politeknik Negeri Ujung Pandang.

$$
\text { Pasali Satrio Prakoso.(2015). }
$$

Kostumisasi Rom Android untuk

Kebutuhan Pengguna Usia Dini.

Makassar: Politeknik Negeri Ujung

Pandang.

Priadi Wahyu \& Nurgiyatna.(2014). Perancangan Sistem Informasi Penjualan Kerajinan Rotan Berbasis Android. Surakarta: Universitas Muhammadiyah Surakarta

Wikipedia. (n.d). Android Studio. Diakses Agustus 05, 2016, dari Wikipedia: http://id.wikipedia.org/wiki/Android_Studi o.

Wikipedia. (n.d). Sumber Daya Alam. Diakses Juli 20, 2016 dari Wikipedia: https://id.wikipedia.org/wiki/Sumber_daya alam

Wikipedia. (n.d). XAMPP. Diakses Juni 13, 2016 dari Wikipedia: https://id.wikipedia.org/wiki/XAMPP Yusro.(2013). Pengertian JSON. Diakses Agustus 20, 2016 darimyusro.info:

http://www.myusro.info/2013/01/pengertia n-json-javascript-object.html 